\title{
Piercing the Veil of Public Policy in the Recognition and Enforcement of Foreign-Related Awards in China
}

\author{
Haoqian Chen ${ }^{*}$, Hailin Bao ${ }^{2}$, Tianyi Zhang2 \\ ${ }^{1}$ University of Warwick, Coventry, UK \\ ${ }^{2}$ Renmin University of China, Beijing, China \\ Email: "haoqian.chen@warwick.ac.uk
}

Received 16 December 2015; accepted 28 February 2016; published 2 March 2016

Copyright (C) 2016 by authors and Scientific Research Publishing Inc.

This work is licensed under the Creative Commons Attribution International License (CC BY). http://creativecommons.org/licenses/by/4.0/

(c) (i) Open Access

\begin{abstract}
This paper analyzed the recognition and enforcement of foreign-related awards in relation to public policy issues from an empirical perspective. The conception of "public policy" in China is vague in the legislative level so this paper conducted holistic summary and analysis of relevant cases in Chinese courts to gradually pierce the veil of public policy.
\end{abstract}

\section{Keywords}

\section{Public Policy Recognition, Enforcement Arbitration}

\section{Introduction}

As the development of China's economy, more foreign companies trade with Chinese companies and they tend to choose arbitration as the way to resolve the disputes because of the peculiarities of arbitration. But the final award issued by arbitral tribunal is only a starting point of the post-award stage, where recognition and enforcement need to be approved for remedies otherwise the award may be viewed as a piece of meaningless paper. Among all the refusal grounds, breach of public policy is frequently invoked by courts. Due to the increasing trades with China, foreign companies are more concerned with the possibilities of recognition and enforcement notwithstanding the ambiguousness of the boundary of public policy. Although many Chinese scholars have conducted much research on public policy, they are mostly theory-oriented. The novelty and purpose of this paper is to pierce the blurred veil of public policy from an empirical perspective along with illustration and comparative interpretation of public policy.

${ }^{*}$ Corresponding author. 
The following parts of this paper start with the elaboration of the relatively ambiguous definition of public policy and its interpretations in US and UK jurisdictions. The third part demonstrates the equally blurred definition of public policy within Chinese legislations, followed by the endeavor to make its definition clearer by analyzing some cases related to breach of public policy. The conclusion not only identifies the scope of the definition of public policy in China but make clear the future trend of the Chinese courts' decision on public policy.

\section{What Is Public Policy?}

Although international arbitration awards are legally binding and final and shall be respected by all the states, parties have recourses to the flawed awards. Setting aside and refusal of recognition and enforcement of the arbitral awards are the usual remedies that parties seek for. Public policy may be the most invoked ground for refusing to enforce the international arbitration award. However, public policy is the most obscure and subjective, the interpretation of which varies from jurisdiction to jurisdiction.

\subsection{Public Policy in the Context of New York Convention}

Public policy exception is provided in the New York Convention Art.V 2(b) that "Recognition and enforcement of an arbitral award may also be refused if the competent authority in the country where recognition and enforcement is sought finds that: [...] The recognition or enforcement of the award would be contrary to the public policy of that country as a refusal of the recognition and enforcement of an arbitral award.” This is a determinative definition of public policy, which is a model clause for the definition of public policy in the UNCITRAL Model Law. Art.36(1)(b)(II) of the Model Law provides that:” Recognition or enforcement of an arbitral award $[\ldots]$ may be refused only [...] if the court finds that $[\ldots]$ the recognition or enforcement of the award would be contrary to the public policy of that state.” Due to the drafters' ambition for worldwide uniform legal standards, Model law Art. 36 follows Convention Art.V not only with respect to public policy but also with respect to the entire structure and content of Art.V which was modeled on (Steiner \& Várady, 2012). As we can see from the above definitions, public policy is used most often as a defense against the enforcement of foreign laws or acts deemed inconsistent with fundamental principles of the forum's legal system. The public policy exception thus enables the forum to protect the sanctity of certain values and minimum standards of justice and morality (Hunter \& Silva, 2003). The public policy exception is invoked broadly in the area of recognition and enforcement of foreign judgments; its appeal lies in the fact that although a foreign law is not subject to control by the forum, a decision rendered by an alien court, through enforcement or lack thereof, can be controlled (Mehren, 1981). When it is used as a defense, the public policy also covers a wide range of issues that cannot be exhausted, including both substantial and procedure grounds. The exception has been used as a catch-all, covering cases of lack of jurisdiction, inadequate notice, and fraud, among others (Mehren \& Patterson, 1974). Although the decisions are not identical, it seems that whenever the recognition and enforcement would prejudice the dignity of the legal forum, the public policy will be successfully invoked (Mehren \& Patterson, 1974). In order to protect the finality and binding effect of arbitral awards, the application of public policy shall be limited, however. According to the international practice that the consent to arbitrate prevails the jurisdiction of court, the party that voluntarily initiates the arbitration normally is estopped from opposing the recognition or enforcement of the resulting award on public policy or other grounds (Mehren \& Patterson, 1974). Thus, public policy shall be limitedly applied and narrowly interpreted on state courts’ decision of enforcement.

\subsection{Interpretation of Public Policy in Different Jurisdictions}

As the understanding and interpretations of public policy vary from state to state, it makes sense for us to analyze how public policy is interpreted and applied in major jurisdictions, which will help us in the process of practicing international arbitration. The analysis will be based on different practices in two major jurisdictions-the U.K. and the U.S.

\subsubsection{The Interpretation of Public Policy in the U.K.}

It seems that the English courts have adopted a restrictive approach of interpreting and applying the public policy as a bar to the enforcement of an arbitral award. Redfern and Hunter once explained that a public policy argument “may lead you from sound law. It is never argued at all, but when other points fail.” (Redfern \& Hunter, 2004). 
It implied that if all other remedies failed, people would turn to public policy. Therefore, in order to prohibit the abuse of public policy as a defense of enforcement of arbitral awards, English courts usually rejected the application of public policy.

In the case of $\mathrm{R} \mathrm{v}$. $\mathrm{V}^{1}$, the arbitration respondent $\mathrm{R}$ entered into a consultant agreement with $\mathrm{V}$ who would help R with the business in North Africa. After making 2 payments to $\mathrm{V}$, the new management of $\mathrm{R}$ rejected to pay the third success fee that had become due. Afterwards, V initiated an ICC arbitration in London in 2006. R defensed that the agreement was virtually contrary to English public policy. The tribunal rendered a final award ordering R to pay the due fee. However, R challenged the award and petitioned to the English courts to refuse to enforce the award on the grounds of public policy. Finally, the Judge held that:” the agreement was not contrary to English public policy" ${ }^{2}$ on the basis that there was not apparent material facts proving that the contract was illegal.

This judgment was in conformity with Redfern and Hunter that:” There is a belief that, so far as international arbitrations are concerned, the parties should be prepared to accept the decision of the arbitral tribunal even if they consider it to be wrong, so long as the correct procedures are observed. If a court is allowed to review this decision on the law or on the merits, the speed and, above all, the finality of the arbitral process is lost. Indeed, arbitration then becomes merely the first stage in a process that may lead, by way of successive appeals, to the highest appellate court at the place of arbitration.” (Redfern \& Hunter, 2004). In light of R v. V judgment, it concludes that the English courts just review the reasoning of the award other than the merits. This approach can be seen as very pro-enforcement and arbitration-friendly. Therefore, English courts regard arbitration as a substitute for, and not merely a preclude to, litigation (Grierson, 2009) and had try their best not to destroy the efforts that the pro-arbitration practitioners had established for the finality and binding effect of arbitration.

\subsubsection{The Interpretation of Public Policy in the U.S.}

U.S. courts' practices of enforcing foreign arbitral awards have consistently conform to the regime established by New York Convention. Therefore, U.S. courts usually interpret public policy narrowly, to guard the parties' consent to arbitrate and the effectiveness of the New York Convention.

The public policy issue stated with the case of Parsons \& Whittermore. In this case, the court noted that "general pro-enforcement bias" present in the New York Convention and opined that a court may refuse to confirm or enforce an arbitral award under the public policy defense only "where enforcement would violate the forum state's most basic notions of morality and justice.” (Reed \& Freda, 2008). Therefore, the Second Circuit court interpreted public policy to be narrowly confined to breaching the forum's most basic notions of morality and justice rather than a widely interpretation of public policy internationally.

The case of Telenor Mobile Communications v. Storm L.L.C. ${ }^{3}$ repeated this position. Telenor and Storm entered into a shareholder agreement with respect rights of the joint venture company Kyistar. A dispute arose and Telenor initiated an arbitration while Storm meanwhile started a legal proceedings in the Ukrainian commercial court. On one hand, the court ruled that the agreement was invalid without the presence of Tenelor. However, on the other hand, the arbitral tribunal ordered that Strom divest its shares. Tenelor sought to enforce the award in New York courts, however Storm requested the court to refuse to enforce on the grounds that the arbitral tribunal's award was contrary to the Ukrainian court's decision and Ukrainian law. According to Storm, by enforcing the award, the New York court would be compelling Storm to violate the law and, further, compelling a party to violate the law was against New York public policy. ${ }^{4}$ This argument ultimately failed.

The Southern District of New York rejected the contention that public policy required the court to decline to enforce a foreign arbitral award where the award had been overturned by a foreign court that colluded with one of the parties. ${ }^{5}$ The court concluded its analysis: Even if there exists a clear public policy in New York against arbitration awards that are in tension with foreign judgments, such a policy cannot trump the well-established and centuries-old policy against enforcement of judgments gained through collusive litigation, whether they be

\footnotetext{
${ }^{1} \mathrm{R}$ v. V [2008] EWHC 1531.

${ }^{2} \mathrm{R}$ v. V [2008] EWHC 1531, at 49.

${ }^{3} 524$ F. Supp. 2d 332 (S.D.N.Y. 2007).

${ }^{4}$ See Karaha Bodas Co., L.L.C. v. Perusahaan Pertammbangan Minyak Dan Gas Bumi Negara, 364 F.3d 274 (5th Cir. 2004) (rejecting contention that enforcing a foreign arbitral award that had been set aside by a foreign court that lacked jurisdiction to set aside the award would violate public policy).

${ }^{5}$ Id. at 356-358.
} 
foreign or domestic. A contrary holding would directly undermine that policy, and reward Storm for its collusive tactics. ${ }^{6}$ Thus, the judgment again showed that how infrequently a court will actually refuse to enforce an arbitral award on public policy grounds. U.S. courts have shown no inclination to stray from the Parsons \& Whitte more reading of the public policy exception. The goals of promoting international arbitration and of fostering international business relations consistently outweigh public policy concerns in the enforcement and confirmation of foreign arbitral awards (Reed \& Freda, 2008).

In conclusion, the strong policy in favor of enforcement of foreign arbitral awards in U.S. resulted in the courts narrowly interpreting and rarely applying of public policy as a refusal of enforcement.

\section{The Blurred Conception of "Public Policy" in Chinese Legislation}

In Chinese legislations, relating to recognition and enforcement, 'public policy' is commonly expressed as “socio-public interests" which enshrines the most fundamental citizens' value orientation in the entire society. For example, Article 274 of Civil Procedure Law of the PRC ${ }^{7}$ stipulates that being contrary to "socio-public interests" can be invoked as a ground to refuse to enforce an award. In addition, Arrangement of the Supreme People's Court (SPC) on Mutual Enforcement of Arbitration Awards (hereafter “Arrangement”) between the Mainland and the Hong Kong Special Administrative Region (HKSAR), ${ }^{8}$ Arrangement between mainland and the Masco Special Administrative Region (MSAR) ${ }^{9}$ and the Provisions on the People's Court's Recognition of the Verdicts on Civil Cases Made by Courts of Taiwan Province ${ }^{10}$ also include such kind of clauses. In other legislations, the word 'socio-public interests' or "social public interests" is also frequently used. For example, such as the Article 58 of Arbitration Law of PRC ${ }^{11}$, the Act of the People's Republic of China on Application of Law for Foreign-Related Civil Relations. $^{12}$

Nonetheless, the boundary and definition of "'socio-public interests" is blurred and ambiguous not with standing the existence of "socio-public interests" in current legislations. Instead of specific stipulation, in the context of increasing international transactions, "public policy" has been embodied in the legal practice of recognition and enforcement of foreign-related awards.

Although the New York Convention has been ratified by China, there are no clear provisions including how to judge the enforceability of foreign-related awards based on Article V (a) and (b) of New York Convention. Therefore, the SPC established the Internal Report Mechanism embodied in the Notice on Several Issues Concerning the People's Court's Handling Relevant Affairs to the Foreign or Foreign-Related Arbitration ${ }^{13}$ where the final verdict on the refusal of recognition and enforcement must be approved by the SPC through a report from IPC to HPC and then to SPC ${ }^{14}$ to prevent "local protectionism” which may lead to arbitrary non-recogni-

\footnotetext{
${ }^{6}$ Id. at 358. In dismissing Storm's argument, the court found American Construction Machinery \& Equipment Corp. Ltd. v. Mechanised Construction of Pakistan Ltd., 659 F. Supp. 426 (S.D.N.Y. 1987) instructive. The court there similarly rejected the notion that a party that conducted litigation parallel to arbitral proceedings in a vexatious manner to undermine the proceedings could later argue that conflicting rulings violated public policy. Id. at 426-29. The court in American Construction Machinery \& Equipment found that declining to enforce the award would violate public policy in such a case. Id. at 429. The Storm court reasoned that Storm's public policy argument failed for the same reasons, and that enforcing the award certainly "would not violate the most basic notions of morality and justice.” 659 F. Supp. at 358 (citing Europcar Italia, S.P.A. v. Maiellano Tours, Inc., 156 F.3d 310, 315 (2d Cir. 1998)).

${ }^{7}$ See Article 274: "If a people's court holds that the enforcement of an arbitration award is contrary to the socio-public interest, the people's court shall issue a ruling not to enforce the award."

${ }^{8}$ See Article 7: If the relevant court finds that under the law of the place of enforcement, the dispute is incapable of being settled by arbitration, then the court may refuse to enforce the award: (3)The enforcement of the award may be refused if the court of the Mainland holds that the enforcement of the arbitral award in the Mainland would be contrary to the public interests of the Mainland, or if the court of the HKSAR decides that the enforcement of the arbitral award in Hong Kong would be contrary to the public policy of the HKSAR.

${ }^{9}$ See Article 11: In case the court of the requested party examines and verifies that there is any of the following circumstances, it shall rule not to recognize the judgment: (6) The recognition and enforcement of the judgment in the Mainland would be contrary to the basic principles of the laws or social public interests of the Mainland; or the recognition and enforcement of the judgment in Macao would be contrary to the basic principles of the laws or public order of Macao.

${ }^{10}$ See Article 9: Verdicts made by Taiwan courts that have any of the following conditions shall not be recognized: (6) The civil case applied for recognition goes against the basic principles of national laws and regulations, or inflict harms to social and public interests.

${ }^{11}$ Article 58: A party may apply for setting aside an arbitration award to the intermediate people's court in the place where the arbitration commission is located if he can produce evidence which proves that the arbitration award involves one of the following circumstances: If the people's court determines that the arbitration award violates the public interest, it shall rule to set aside the award.

${ }^{12}$ See Article 5: If the application of foeign laws will damage the social public interests of the People's Republic of China, the laws of the People's Republic of China shall apply. The Act was adopted at the $17^{\text {th }}$ Session of the Standing Committee of the $11^{\text {th }}$ National People's Congress on 28 October 2010 and came into force on 1 April 2011.

${ }^{13}$ [1995] fa fa No 18, issued by the SPC on 28 August 1995 and effective as of the same date.
} 
tion and non-enforcement of foreign-related awards to ensure legitimate discretion rights. The process of request from IPC to HPC and HPC to SPC is called Inquiry (qingshi) system and the ultimate decision from SPC is called Response (dafu) system. These two systems constitute the Internal Report Mechanism through which the decision-making authority is shifted from lower courts to SPC. ${ }^{15}$ (Wan, 2009). Moreover, the SPC routinely publishes Guide on Foreign-Related Commercial and Maritime Trials including inquiries and responses in order to increase the transparency of reviewing international arbitration.

\section{Pierce the Veil of "Public Policy" from an Empirical Perspective}

This part collects all the cases shown in Table 1 associated with the recognition and enforcement of foreign-related awards where public policy issue arises since 1992. Public policy in China is ambiguous and it is difficult to give an explicit definition of public policy but it is possible to make the blurred scope clearer. This paper's approach to the issue, as shown in Figure 1, is to exclude the external conditions by negative analysis and to confirm the internal conditions by positive analysis from an empirical perspective. But there is still a remaining blurred area that will change as the development of society and culture and the SPC can gradually narrow the remaining blurred area by positive and negative decisions.

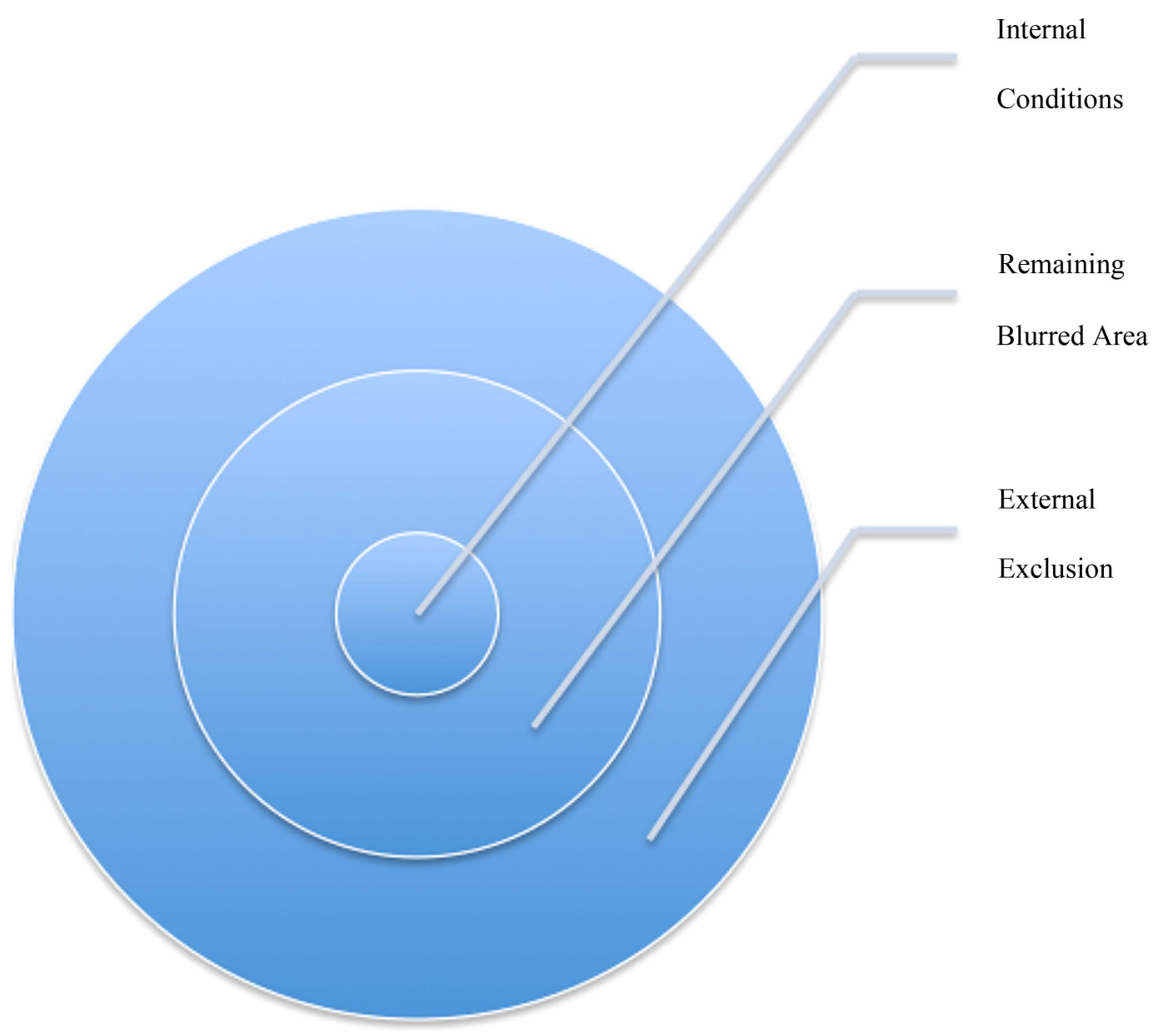

Figure 1. Current scope of public policy.

\footnotetext{
${ }^{14}$ Ibid, Article 2.

${ }^{15}$ This Mechanism reduces the possibility of non-enforcement of foreign-related awards and thus indicates a pro-enforcement bias. See Wan, “Judicial Practice with regard to the New York Convention in China” (2009) 276(2) Journal of Law Application 5.
} 
Table 1. Cases summary related to public policy.

\begin{tabular}{|c|c|c|c|}
\hline No. & Cases & Reasoning & $\begin{array}{l}\text { Whether the } \\
\text { award is refused } \\
\text { to recognize and } \\
\text { enforce }\end{array}$ \\
\hline 1 & $\begin{array}{c}\text { USA Productions and Tom } \\
\text { Hulett \& Associates v. } \\
\text { China Women Travel Service }(1997)^{16}\end{array}$ & $\begin{array}{l}\text { The performance of heavy metal music } \\
\text { was contrary to China's actual conditions } \\
\text { and thus contravened China's socio-public interests. }\end{array}$ & Yes. \\
\hline 2 & $\begin{array}{l}\text { ED \&F Man (HK) Co, Ltd v China } \\
\text { National Sugar \& Wines Group Corp (2004) }\end{array}$ & $\begin{array}{l}\text { A violation of mandatory rules did not } \\
\text { necessarily constitute a violation of public policy, }\end{array}$ & No. \\
\hline 3 & $\begin{array}{l}\text { Pepsi (China) v Sichuan } \\
\text { Yunlu Industrial Development }\end{array}$ & $\begin{array}{l}\text { Corruption was proposed as a breach of public policy } \\
\text { but the SPC did not focus on the corruption issue but rather } \\
\text { refuse the enforcement on the ground that the arbitral procedure } \\
\text { was not in accordance with the agreement of the parties. }\end{array}$ & Yes. \\
\hline 4 & Pepsi v Sichuan Yunlu Industrial Development & Ibid. & Yes. \\
\hline 5 & Mitsui v. Hainan Textile (2005) ${ }^{18}$ & $\begin{array}{l}\text { A breach of administrative regulations and } \\
\text { mandatory administrative rules did not per } \\
\text { se amounts to a breach of PRC public policy. }\end{array}$ & No. \\
\hline 6 & $\begin{array}{l}\text { Bunge Singapore v. } \\
\text { Fengyuan Grain (2007) }\end{array}$ & $\begin{array}{l}\text { The procedure was not in accordance with the FOSFA Rules } \\
\text { of Arbitration and Appeals (2001). And the SPC implicitly } \\
\text { approved that a breach of an administrative import } \\
\text { ban cannot in itself constitutes a breach of public policy. }\end{array}$ & Yes. \\
\hline 7 & $\begin{array}{l}\text { Shin-Estu Chemical v. } \\
\text { Zhongtian Technology }(2008)^{20}\end{array}$ & $\begin{array}{l}\text { The SPC kept silence on the debate whether harming } \\
\text { the industry of optical fiber constitutes a breach of PRC } \\
\text { public policy and refused base on Arbitral Tribunal's } \\
\text { failure to notify the parties of the extension of the deadline. }\end{array}$ & Yes. \\
\hline 8 & Shin-Estu Chemical v. Xinmao Science (2008) ${ }^{21}$ & Ibid. & Yes. \\
\hline 9 & $\begin{array}{l}\text { Amulong Steel v. } \\
\text { Ni-Co Mineral et al. }(2009)^{22}\end{array}$ & $\begin{array}{l}\text { The courts kept silence over this public policy } \\
\text { issue even it was proposed by one party. }\end{array}$ & Yes. \\
\hline 10 & $\begin{array}{l}\text { GRD Minproc v. } \\
\text { Shanghai Flyingwheel (2009) }\end{array}$ & $\begin{array}{l}\text { The question of the substantive fairness of the decision } \\
\text { made in the Arbitral Award was irrelevant when determining } \\
\text { whether the Arbitral Award breached PRC public policy. }\end{array}$ & No. \\
\hline
\end{tabular}

\footnotetext{
${ }^{16}$ See Reply of the SPC Concerning the Request by USA Productions and Tom Hulett \& Associates for Recognition and Enforcement of the Award concerning to contract disputes (1997) 35. 《最高人民法院关于北京市第一中级人民法院不予执行美国制作公司和汤姆·胡莱特 公司诉 中国妇女旅行演出合同纠纷仲裁裁决请示的批复》 他[1997]35 号 1997 年 12 月 26 日

17 《最高人民法院关于 ED\&F 曼氏(香港)有限公司申请承认和执行伦敦糖业协会仲裁裁决案的复函》([2003]民四他字第 3 号) See Reply of the SPC Concerning the Request by the ED \& F Man (HK) Co, Ltd for Recognition and Enforcement of the Arbitral Award of the Arbitration Institute of the Sugar Association of London (2004) 7 Guide on Foreign Trials 12-17.

${ }^{18}$ See Reply of the SPC to the Request for Instructions on Rejection Held by the Haikou IPC on Recognition and Enforcement of an SCC Arbitral Award, (2001) SPC 4th Civil Chamber No. 12] (WAN E'xiang (ed.), China Trial Guide: Guide on Foreign-Related Commercial and Maritime Trial vol. 11, 109-112 (People's Court Press 2005:2).《最高人民法院关于对海口中院不予承认和执行瑞典斯德哥尔摩商会仲 裁院仲裁裁决请示的复函》[2001]民四他字第 12 号

${ }^{19}$ 《最高人民法院关于邦基农贸新加坡私人有限公司申请承认和执行英国仲裁裁决一案的请示复函》[2007] 民四他字第 41 号 [Reply of the SPC to an Application by Bunge Agribusiness Singapore Pte Ltd for the Enforcement of an English Award, (2007) SPC 4th Civil Chamber, Others No. 41]

${ }^{20}$ 《最高人民法院关于不予承认日本商事仲裁协会东京 04-05 号仲裁裁决的报告的复函》[2007]民四他字第 26 号 [Reply of the SPC on a Proposal to Refuse Recognition of the Arbitral Award No. 04-05 Rendered by the Japan Commercial Arbitration Association, (2007) SPC 4th Civil Chamber No. 26]

${ }^{21}$ 《最高人民法院关于不予承认日本商事仲裁协会东京 04-05 号仲裁裁决的报告的复函》[2007]民四他字第 26 号 [Reply of the SPC on a Proposal to Refuse Recognition of the Arbitral Award No. 04-05 Rendered by the Japan Commercial Arbitration Association, (2007) SPC 4th Civil Chamber No. 26]

22《最高人民法院关于不予承认日本商事仲裁协会东京 04-05 号仲裁裁决的报告的复函》[2007]民四他字第 26 号 [Reply of the SPC on a Proposal to Refuse Recognition of the Arbitral Award No. 04-05 Rendered by the Japan Commercial Arbitration Association, (2007) SPC 4th Civil Chamber No. 26]

${ }^{23}$ 《最高人民法院关于 GRD Minproc 有限公司申请承认并执行瑞典斯德哥尔摩商会仲裁院仲裁裁决一案的请示复函》[2009]民四他 字第 48 号 [Reply of the SPC on the Case Regarding an Application by GRD Minproc Ltd for Recognition and Enforcement of an SCC Arbitral Award, (2009) SPC 4th Civil Chamber, Others No. 48] (WAN E'xiang (ed.), China Trial Guide: Guide on Foreign-Related Commercial and Maritime Trial vol. 18, 135-142 (People’s Court Press 2009:1)).
} 


\section{Continued}

Hemofarm DD et al. v. Yongning Pharmaceutical (2009) ${ }^{24}$

LM Holdings et al. v. Jiashijie Group et al.

14 Tianrui Investment v. Yiju Hotel (2010) ${ }^{27}$

15

16

18

19 $(2009)^{26}$

Noble Resources v. Zhonghai Cereals and Oils (2009) ${ }^{25}$

\section{JapaneseShin-Etsu Chemical}

Co, Ltd v Jiangsu Zhongtian

Polytron Technologies Inc (2010) ${ }^{28}$

Louis Dreyfus Commodities

Asia v Guangdong Fuhong Edible Co, Ltd (2010) ${ }^{29}$

PROFILIA of West Germany (Far East) v Hubei Yingtai (2011)

JA Apparel v. Judger Group et al. (2011)

Western Bulk Pte Ltd v Beijing Sinosteel Tiantie Iron \& Steel Trade Co, Ltd (2012) ${ }^{31}$
By denying the legality and appropriateness of the jurisdiction of China courts, the Arbitral Tribunal disregarded the PRC's judicial sovereignty, and the re-judging of issues already decided by the Ji'nan IPC disregarded the jurisdictional sovereignty of the Chinese courts and the res judicata effect of Chinese court decisions. It was also inappropriate and unfair to order Yongning Pharmaceutical to pay damages caused by the preservation of property issued by the Ji'nan IPC. All this constituted a violation of PRC public policy.

The SPC could not find evidence indicating that the Goods would cause any harm to public health.

Yes.

The SPC refused to enforce the award because the arbitration proceedings were not in accordance with the ICC Rules of Arbitration (1998) and the arbitration clause although the public policy issue was proposed.

A violation of mandatory rules did not necessarily constitutes a violation of public policy,

Supra No.9 or 10 .

Yes.

The arbitrator's misunderstanding that there are obvious distinctions between formulated provisions and practical application did not suffice to a breach of public policy.

The IPC claimed that the enforcement would result in loss of state-owned property, thereby constituting a breach of public policy but this claim was then overruled by SPC.

A violation of the mandatory provisions of a state's law does not necessarily constitute a violation of that state's public policy.

The SPC asserted that public policy should be interpreted and applied strictly and the court refused the enforcement because of lack of appropriate appointment of an arbitrator.

24《最高人民法院关于不予承认和执行国际商会仲裁员仲裁裁决的报告的复函》[2008]民四他字第 11 号 [Reply of the SPC to the Request for Instructions on Denying Recognition and Enforcement of an ICC Arbitral Award, (2008) SPC 4th Civil Chamber No. 11] (WAN E'xiang (ed.), China Trial Guide: Guide on Foreign-Related Commercial and Maritime Trial vol. 18, 124-134 (People's Court Press 2009:1)).

${ }^{25}$ See the SPC Reply on the Case Regarding the Application by Zhoushan Zhonghai Cereals and Oils Industry Co. Ltd for Refusal to Enforce an HKIAC Arbitral Award, (2009) SPC 4th Civil Chamber, Others No. 2] (WAN E'xiang (ed.), China Trial Guide: Guide on Foreign-Related Commercial and Maritime Trial vol. 18, 143-150 (People’s Court Press 2009:1)).

${ }^{26}$ 《最高人民法院关于不予承认和执行国际商会洛桑 12330/TE/MW/AVH 仲裁裁决的请示的复函》[2009]民四他字第 38 号 [Reply of the SPC to the Request for Instructions on a Refusal to Recognize and Enforce an ICC Lausanne Arbitral Award, (2009) SPC 4th Civil Chamber No. 38] (WAN E'xiang (ed.), China Trial Guide: Guide on Foreign-Related Commercial and Maritime Trial vol. 19, 111-125 (People's Court Press 2009:2)).

${ }^{27}$ 《最高人民法院关于申请人天瑞酒店投资有限公司与被申请人杭州易居酒店管理有限公司申请承认仲裁裁决案的请示报告的复函 [2010]民四他字第 18 号 [Reply of the SPC on the Applicant Tianrui Hotel Investment Co. Ltd and the Respondent Hangzhou Yiju Hotel Management Co. Ltd's Request on Recognition of an Arbitral Award, (2010) SPC 4th Civil Chamber No. 18] (WAN E'xiang (ed.), China Trial Guide: Guide on Foreign-Related Commercial and Maritime Trial vol. 20, 94-99 (People's Court Press 2010:1)).

${ }^{28}$ See Reply of the SPC Concerning the Request for Refusal to Recognize the Arbitral Award No 07-11 of Japan Commercial Arbitration Association (Tokyo) (2011) 21 Guide on Foreign Trials, 122-143.

${ }^{29}$ See Reply of the SPC Concerning the Request by Louis Dreyfus Commodities Asia for Recognition and Enforcement of the Arbitral Award No 3980 of the Federation of Oils, Seeds and Fats Associations (2012) 22 Guide on ForeignTrials 181-188.

${ }^{30}$ See JA Apparel v. Judger Group et al. (2011), Shanghai No. 1 IPC, 30 June 2011, available at

http://0-www.kluwerarbitration.com.pugwash.lib.warwick.ac.uk/CommonUI/document.aspx?id=KLI-KA-CACDS-E-107\#note*.

${ }^{31}$ See Reply of the SPC Concerning the Request by Western Bulk Pte Ltd for Recognition and Enforcement of the British Arbitral Award (2013) 24 Guide on Foreign Trials 115-124. 


\subsection{Whether Violation of Law of the Forum of Recognition and Enforcement Constitutes a Breach of Public Policy-Narrowing External Scope by Negative Analysis}

Being contrary to that public policy can be invoked as a ground to refuse recognition and enforcement under Article V(2) (b) of the New York Convention, ${ }^{32}$ can local courts refused the enforcement merely due to a breach of public policy when they find that the arbitral award violates the domestic law? In China, the answer is no. The first reason is that it can be considered as an intervention of substantial merits of arbitral award. In China, the mechanism of reviewing arbitral awards is a two-track approach, where courts are able to review substantial merits and procedure issues of domestic awards based on Article 217 of Civil Procedure Law of PRC ${ }^{33}$ and only procedure issues of foreign-related awards. ${ }^{34}$ Some relevant cases in China manifests that judges in lower courts reach their hands too far on merits of awards. In Tianrui Investment v. Yiju Hotel ${ }^{35}$, the Hangzhou IPC held that the contract of whose nature is a franchise agreement was null and void because Tianrui Investment registered in Samoan Islands could not directly engage in franchising business in China, contrary to Article 3 of MOFCOM's Measures for the Administration of Foreign Investment in Commercial Fields $(2004)^{36}$ that stipulates that a foreign company shall engage in franchise operations through a foreign-invested company registered in China and Article 10 of the SPC Interpretation I on the PRC Contract Law (1999) ${ }^{37}$, thereby violating PRC public policy. But the SPC claimed that there was no violation of domestic law because of the State Council's Regulation on Commercial Franchise Administration (2007). ${ }^{38}$ To prevent the "local protectionism” from being employed to abuse judicial power, such as Hangzhou IPC in this case, where local courts have obvious incentive to refuse to enforce through examining the merit of awards, violation of domestic law shall not be utilized as a tool to support the public policy refusal. The second reason is the arbitrators' plight. Normally arbitrators only need to consider applicable law chosen by parties. However, if violation of mandatory law of the forum of enforcement leads to a breach of public policy, it means that arbitrators need to take law of forum of enforcement into consideration other than the chosen governing law. On the one hand, arbitrators may be compelled to consider both of the laws because they need to make efforts to achieve the purpose of the arbitration and mitigate the awards' risk of being refused. An award that cannot be enforced may be viewed equally to an invalid one. On the other hand, it is worth noting that what is the purpose for the parties to unanimously choose a law governing the merit if arbitrators still refer to both laws and how arbitrators can balance when facing to the conflict between chosen governing law and the laws of the forum of enforcement.

Therefore, in some recognition and enforcement cases reported to the SPC including ED \&F Man (HK) Co, Ltd v China National Sugar \& Wines Group Corp, Mitsui v. Hainan Textile, Bunge Singapore v. Fengyuan Grain, Tianrui Investment v. Yiju Hotel, Louis Dreyfus Commodities Asia v Guangdong Fuhong and JA Apparel v. Judger Group et al., it was held that contravening mandatory Chinese law does not necessarily constitutes a breach of public policy despite some lower courts' decisions to refuse to enforce. The initial case is ED \&F Man (HK) Co, Ltd v China National Sugar \& Wines Group Corp, where it was held that violation of mandatory Chinese law that stipulates that "domestic enterprises were not allowed to conduct overseas futures transactions without

\footnotetext{
${ }^{32}$ Article V(2)(b): Recognition and enforcement of an arbitral award may also be refused if the competent authority in the country where recognition and enforcement is sought finds that: (b) The recognition or enforcement of the award would be contrary to the public policy of that country.

${ }^{33}$ Article 217: 'If the party against whom the application is made furnishes proof that the arbitral award involves any of the following circumstances, the people's court shall, after examination and verification by a collegial panel, make a written order not to allow the enforcement: (4) the main evidence for ascertaining the facts is insufficient. (5) there is definite error in the application of the law; (6) the arbitrators have committed embezzlement, accepted bribes or done malpractice for personal benefits or perverted the law in the arbitration of the case.

${ }^{34}$ The reason for the divergence between domestic awards and foreign-related award is that China ratified New York Convention that does not permit any review on the substantial merits of awards. This is also cited by the Supreme Court of India in Remusagar Power Co Ltd v General Electric Co., (1995) XX Year book Commercial Arbitration 681 at 69.

${ }^{35}$ Supra, note 14.

${ }^{36}$ Article 3: The "foreign-funded commercial enterprises" shall refer to the enterprises with foreign investment which undertake the following business activities: 4. Franchising: authorizing other people with using its trademark, trade firm, or mode of management through signing contract for gaining remunerations or franchising fees. Foreign companies, enterprises, and other economic organs or individuals shall carry out the business activities as prescribed in items $1,2,3$, and 4 of the preceding paragraph through foreign-funded enterprises established within China.

${ }^{37}$ Article 10: Where the parties entered into a contract the subject matter of which was outside their scope of business, the People's Court shall not invalidate the contract on such ground, except where conclusion of the contract was in violation of state restriction concerning, or licensing requirement for, a particular business sector, or in violation of any law or administrative regulation prohibiting the parties from participation in a particular business sector.

${ }^{38}$ The Regulation came into effect on 1 May 2007. According to this regulation, a company intending to conduct franchising business had to conclude a commercial franchise agreement and report such agreement to the competent administrative authorities for record purposes only.
} 
obtaining prior approval from the competent authority” making the contract invalid was not equal to be contrary to public policy, after which the following cases kept consistent opinions.

\subsection{What Constitutes a Breach Public Policy-Identifying the Internal Scope by Positive Analysis}

Since 1992, the SPC refused the enforcement invoking the ground of a breach of public policy in only two cases, USA Productions and Tom Hulett \& Associates v. China Women Travel Service and Hemofarm DD et al. v. Yongning Pharmaceutical, which are positive affirmation of internal conditions.

In USA Productions case, "Southern Band" breached the contract and performed heavy metal music. The SPC asserted that the award could not be recognized and enforced because the performance of heavy metal music contravened the China's actual conditions and infringed the socio-public interest. However, this application of public policy that has been changed significantly afterwards was based on the old Chinese society culture and custom. It is unreasonable to apply this standard into current practice.

In Hemofarm case, the Chinese company, Yongning Pharmaceutical, contended before the local court of which jurisdiction was objected based on the arbitration agreement by Hemofarm JV, a joint venture created by Hemofarm DD, MAG and Yongjin, to claim Hemofarm JV for the rental fees and the return of property. But the Jinan IPC held that the dispute arose based on the rental contract between Yongning and Hemofarm JV rather than the joint venture contract where there was an arbitration agreement and thus decided to reject the jurisdiction objection and delivered a verdict. Hemofarm JV appealed but the HPC dismissed the appeal. Afterwards, Yongning also initiated another two proceedings and won both cases. In September 2004, Hemofarm DD submitted the dispute to arbitration and the Arbitral Tribunal reached an opposite conclusion to the IPC and HPC, declaring that IPC and HPC had no jurisdiction on this dispute and Yongning Pharmaceutial thus breached the contract. Then Hemofarm DD requested the IPC for the recognition and enforcement. However, the request was refused and the SPC declared that the Arbitral Tribunal's ignorance on the Chinese court decisions was viewed as indifference on the China's judicial sovereignty and sacred res judicata effect of the three decisions made by IPC constituting violation of public policy.

The two cases illustrated that violating the China's actual conditions that has been changing over time, and disregarding the legality and res judicata of decisions made by Chinese courts and judicial sovereignty are both identified as a breach of public policy and enforcement with these issues will be refused.

\section{Conclusion}

Although different jurisdictions adopt different interpretation and application of public policy when facing the request of refusal of enforcement of an international arbitral award, it seems that U.K. and U.S. courts reached a consensus to narrowly interpret and restrictedly apply public policy. Both the U.K. and U.S. courts are confined to touching merely the procedural public policy rather than the merits, thus making the public policy much clearer when applied than it could be interpreted. The New York Convention was virtually established to promote the international transactions and investment and to effectively protect the rights of the contracting parties, the abuse of public policy to refuse enforcement will destroy the effort to establish an international mechanism to protect the parties in the international transactions. The courts' precedents and practices regarding public policy are demonstrating the finality and binding effects of international arbitral awards, and thus making international arbitration more convincing and more popular to be chosen as a transnational dispute resolution.

But in China, a civil law legal system jurisdiction, where legislations are the main legal basis, public policy remains blurred. Nevertheless, in order to pierce the ambiguous veil of public policy, according to the decisions made by the SPC, the blurred scope of public policy is becoming clearer by being narrowed externally and expanded internally. As the change of society culture, background and legislations, the internal identified scope of public policy is steadily changing. The empirical study in this paper is also a good reference for foreign companies which reach an arbitration agreement with Chinese companies to know the profile of public policy in China, thereby bearing the potential risk of refusal of recognition and enforcement in mind.

\section{References}

Grierson, J. (2009). Court Review of Awards on Public Policy Grounds: A Recent Decision of the English Commercial Court Throws Light on the Position under the English Arbitration Act 1996. MEALEY'S International Arbitration Report, 24, 1-9. 
Hunter, M., \& Silva, G. C. E. (2003). Transnational Public Policy and its Application in Investment Arbitrations. The Journal of World Investment \& Trade, 4, vii-378.

Mehren (1981). Recognition and Enforcement of Foreign Judgments-General Theory and the Role of Jurisdictional Requirements. RECUEIL DES COURS: COLLECTED COURSES OF THE HAGUE ACADEMY OF INTERNATIONAL LAW 1980, Issue II, vii-47.

Mehren, \& Patterson (1974). Recognition and Enforcement of Foreign-Country Judgments in the United States. LAW \& POL'Y INT'L Bus, No. 6, vii-37, 61.

Redfern, A., \& Hunter, M. (2004). Law and Practice of International Commercial Arbitration (4th ed.: Volume 421). London: Sweet \& Maxwell.

Reed, L. F., \& Freda, J. (2008). Narrow Exceptions: A Review of Recent U.S. Precedent Regarding the Due Process and Public Policy Defenses of the New York Convention. Journal of International Arbitration, 25, 649-656.

Steiner, S. B., \& Várady, T. (2012). Public Policy as Ground for Refusal of Recognition of Foreign Arbitral Awards with Special Focus on Austria and Hungary. Budapest: CEU, Budapest College.

Wan, E. X. (2009). Judicial Practice with regard to the New York Convention in China. Journal of Law Application, No. 5, vii-276(2).

Wan, E. X. (Ed.) (2009). China Trial Guide: Guide on Foreign-Related Commercial and Maritime Trial, Vol. 18, vii-143-150. 